\title{
DETERMINANTS OF BEHAVIORAL INTENTION IN AGROTOURISM VISITING
}

\author{
Riana Fitria Dina*, Koestiono Djoko, Setiawan Budi, Muhaimin A. Wahib \\ Doctoral Program in Agricultural Science, Faculty of Agriculture, \\ University of Brawijaya, Indonesia \\ *E-mail: fitria.fp@ub.ac.id
}

\begin{abstract}
Tourism is one of the key supporting sectors in Indonesian economy which has significant contribution to its GDP. Lately, agri-tourism becomes a featured product of Indonesian tourism in various scales. Even if it grows in a significant way, but developing agri-tourism still need additional support from related parties, especially from consumers. Customers' satisfaction has a crucial impact in determining their loyalty and behavior, and also affects the sustainability of agri-tourism business. Any problem on these fields can hold up the agritourism development. This research is aimed to analyze the effect of service quality, customer's value, livelihood assets, destination image, and performance of local government on behavioral attention of agri-tourism's visitors. This research employed structural equation modeling (SEM) using WarpPLS software. The results indicate that both service quality of agri-tourism and quality of human resource have significant effects on relationship marketing, customers' satisfaction, and behaviora intention. Moreover, livelihood assets aspect also has affected the customers' behavioral attention significantly.
\end{abstract}

\section{KEY WORDS}

Agri-tourism, behavioral intention, livelihood asset, agribusiness, management.

Tourism is one of the important sectors in the Indonesian economy, which tourism holds a great contribution to local revenue and state revenue. One of the elements in the agricultural sector that currently has a great potential to be developed is agritourism. The potency of agritourism is addressed to the natural beauty of agriculture and the production of the developing agricultural sector. Agritourism is a series of tourism activity that uses the agricultural potency as the tourist attraction, both the potential scenery in the agricultural area, the specific characteristic, and the diversity of production activities and the agricultural technology, and the culture of the farming community. Agritourism is aimed at broadening knowledge, recreational experience, and business relationship in the agricultural sector including staple foods, horticultural products, plantation, fisheries, and livestock farming. In addition, the agritourism development is also aimed at regional agricultural development, improving the farmer's welfare, the utilization of regional potency, ecological balance, the employment opportunities for local residents, stimulating the growth of the organization supporting agritourism, and improving the marketing attempt for agricultural products.

Batu City, Malang Regency, and Malang City are three administrative areas that are integrated with the area for development and they are the epicenter of tourism in East Java Province. Batu City and Malang Regency provide many agritourism destination concepts, while Malang City plays a role as the support for the provision of facility and tourism service. It is in line with a statement by Soemarno (1999) that rural areas and remote areas can be the production center, the location of tourism, while the central area or the urban area can be a tourism service area.

Some regions in the Greater Malang begin to develop the agritourism activity as a part of the concept of tourism village development. Even in some locations, agritourism is also presented based on themes, such as agritourism for education, scientific agritourism or agritourism for research, agritourism for health for the elders, and the tourism for teens and family in form of outbound.

Every manager of agritourism applies different management. In modern management, quality is the main standard for the success of a business. The core thing of every business 
is marketing, and the success of marketing is mostly determined by customer satisfaction. Total Quality Management is a customer satisfaction-oriented management system. According to Deriawan (2015), quality performance and relationship marketing are also important things for determining customer satisfaction. The destination image has a correlation with the quality performance that is considered as customer loyalty and it is in line with a research conducted by Jankingthong (2012). In this research, behavioral intention is also related to the aspect of the livelihood of the visitor and the regional government performance in facilitating tourism development. Based on a research done by Halima Begum (2014), the role of government gives an impact on customer's perception for the tourism sustainability. In addition, the researcher expected that the livelihood of the customer is a new variable assumed to have an impact on Behavioral Intention. According to Parasuraman (1985), the dimension of behavioral intention is in form of recommendation, repurchase intention, and pay more.

A consumer as the subject who uses agritourism services tends to change their behavior. The external stimulus with the existence of another object that is more interesting can make customer behavior changes. The customer loyalty will be maintained through trustworthiness and a commitment. All of them can happen from the consumer satisfaction in using a service. Therefore, the research on consumer behavior i.e. Behavioral Intention as the motivation for tourism development in the Greater Malang.

Nowadays, there is numerous agritourism with various concepts in the Greater Malang. A large-scale agritourism business with a strong capital has relatively developed and it has a good management standard. Nevertheless, the small and micro-scale agritourism owned by the farmers or managed by the community individually and the farmer groups do not have a good management standard. In general, small-scale agritourism has fewer visitors, low customer's loyalty, no adequate facility, no standardization in product quality and service, and less promotion.

The sustainable agritourism development needs to be supported by all relevant aspects, from both the key of marketing i.e. consumers and the individual side of the manager, social, resource, financial, and the physical conditions of agritourism. Therefore, a research on visitors' Behavioral Intention is needed. This research aimed to analyze the influence of quality performance, customer value, the livelihoods assets of the visitor, destination image, and regional government performance towards the Behavioral Intention of agritourism visitors in the Greater Malang.

\section{LITERATURE REVIEW}

Consumer behavior is an important and complicated concept in marketing management. This conception is important because it contains a prediction and an expectation of a marketer about consumer behavior since the initiation of purchase ideas up to the post-purchase conditions. A consumer behavior is defined by Setiadi (2010) as an action that is directly involved in acquiring, consuming, and using a product or service, including the decision that precedes this decision. This definition emphasizes three groups of the process including i.e. pre-purchasing, purchasing, and post-purchasing.

According to Kotler (2001), the factors that influence consumer behavior are the social factor, internal factor, and psychological factor. The social factor consists of culture, subculture, social class, reference group, family, and social status. The internal factor consists of age and the stages of the human life cycle, occupation, economic situation, lifestyle, and personality and self-concept. Meanwhile, the psychological factor consists of motivation, perception, learning, belief, and attitude.

In this research, the variables used and expected to influence the consumer behavior especially the visitor behavioral intention are performance quality of destination, performance quality of human resources, the livelihood of the visitor, destination image, customer value, relationship marketing, consumer satisfaction, and the regional government performance. A quality is an effort to meet a number of factors towards the effectiveness and efficiency of company goal achievement. The factors referred to the product and service that becomes a 
marketing tool to achieve profitability. Through the concept, a rational and subjective measurement can be created by the product providers and the users. However, basically, quality remains come from customer perception as the final user of the product offered.

An image is the combination of emotion and cognitive components in an individual so that it cannot be clearly predicted. Therefore, the company must keep and maintain the company image as it is so that it can always give a positive impact on the survival of the company (Davidoff, 1994). Related to the agritourism destination in this research, destination image should always be maintained to ensure an increase in number of visitors in the future.

The customer value can be divided into two big categories: a value that is perceived by the customer and the value expected by the customer. The value perceived by the customer is defined as a comparison between benefit and sacrifice of product or service performance. Meanwhile, the expected value is the customer's emotional attitude towards the expected ideal product and service (Parasuraman, 2000).

Another variable used here is customer/consumer satisfaction. According to Kotler (2001), the definition of customer satisfaction is as follows: Customer satisfaction is about the assumption on the performance of a product or service whether it has met the customer expectation or not. If the performance of a product is lower than customer expectation, the customer is not satisfied, and if the achievement matches or exceeds the customer expectation, the customer is satisfied.

Relationship marketing is a process to create, maintain, and improve the strong relationships with the customers and other stakeholders. According to Kotler (2001), the dimension of relationship marketing comprises trustworthiness, commitment, communication, and the ability to mitigate a conflict.

Another variable that is important in this research is the livelihood of the customer. According to Can (2013), etymologically, the definition of livelihood involves an asset (nature, human, financial, social, and physics), activities in which the access of the assets is mediated by an institution and social relations that dictate the results obtained by individuals and families simultaneously. The livelihood condition, in terms of character, social influence, financial, physical, and affecting nature are expected to be one of the indicators in consumer behavior.

Consumer behavioral intention is frequently based on the possible action that will be performed by the consumer. Behavioral intention is defined as consumer expectation to behave according to a certain way such as to own, discard, and to use a product or service. Thereby, the consumer is able to create an expectation to find information, to tell other people related to their experience when using a product, purchasing a certain product or service, and discarding the product in a certain way.

According to Peter and Olson (2013), behavioral intention is a proposition that relates someone to future actions. Parasuraman (2000) stated, "Behavioral intentions can be viewed as indicators that signal whether customers will remain with or defect from the company." The definition implies that behavioral intention can be seen as an indicator that signals whether the customer will remain with or defect from the company's product or service. Behavioral Intention is divided into three dimensions: Recommendation, Repurchase Intention, and Pay More. A recommendation is a behavioral intention of someone to encourage the customer's friends or relatives to use a product or service from a company or recommends the company to other people. This indicated that they had performed the marketing for the company indirectly and they invited the consumers to the company. Repurchase intention is a behavioral intention of someone to use a product twice or more. Meanwhile, pay more is a behavioral intention that is occurred as the result of consumer satisfaction towards a business entity such as the consumer's willingness to pay even though the price becomes more expensive.

\section{METHODS OF RESEARCH}

The number of respondent was 130 visitors from thirteen agri-tourism objects in Malang as the most potential regency on agricultural and tourism sector, especially in East 
Java. Data analysis method employed was Structural Equation Modeling (SEM) using Warp PLS software.

\section{RESULTS AND DISCUSSION}

In this research, the agritourism data of Batu city was represented by Bumiaji District while the agritourism data of Malang Regency was represented by Poncokusumo District. Based on those data, those districts played a big role in agritourism development especially in small-scale (individually/in-group). From the objective stated above i.e. analyzing the influence of quality performance, customer value, livelihoods assets, destination image, and the regional government performance toward the Behavioral Intention of the agritourism visitor in the Greater Malang, it was obtained a result based on Structural Equation Modeling (SEM) analysis used WarpPLS software as follows.

Outer-Model Assessment. The assessment of reflective outer model could be accepted using the result of Indicator Reliability, i.e. it was assessed based on the value of variance from the indicators to explain the latent variables. The value of the load factor for each variable was $0.6-0.7$. It means that those variables were qualified for explanatory research. Overall, the internal consistency reliability that was seen from the value composite reliability and aimed to measure the reliability of latent variable using the indicator had a value of $0.6-$ 0.7. It means that it was qualified for explanatory research. Meanwhile, the Convergent validity, an assessment used for measure the correlation between the reflective indicators with the latent variable score, had a value of $>0.5$ indicating that it was accepted for explanatory research.

Outer-Model Assessment. The structural model assessment or inner model with PLS could be seen from the percentage of variance that had been explained i.e. by seeing the $R^{2}$ value to measure the impact between the latent variables. In this research, $R^{2}$ value based on the R2 value of Relationship Marketing (RM) latent variable was 0.29 . It shows that the diversity of RM latent variable could be explained by the latent variable of customer value and quality performance of $29 \%$ while the rest i.e. $71 \%$, was the contribution of other variables that were not discussed in this research.

The local visitor satisfaction had an $R^{2}$ value of 0.52 , indicating that the diversity of visitor satisfaction could be explained by the customer value $\left(X_{1}\right)$, quality performance $\left(X_{2}\right)$, and Relationship Marketing $\left(\mathrm{Y}_{1}\right)$ of $52 \%$, while the rest, $48 \%$, was the contribution of other latent variables that influenced visitor satisfaction, which was not discussed in this research.

According to the $R^{2}$ value, Behavioral Intention $\left(B_{1}\right)$ had a value of 0.34 . It indicated that the diversity of $\mathrm{BI}$ could be explained by customer value $\left(\mathrm{X}_{1}\right)$, Quality Performance $\left(\mathrm{X}_{2}\right)$, the Livelihood of the Visitor $\left(X_{3}\right)$, Regional Government Performance $\left(X_{5}\right)$, and Visitor Satisfaction $\left(\mathrm{Y}_{2}\right)$ of $34 \%$; Meanwhile the rest, $66 \%$, was the contribution from other variables that were not discussed in this research.

The next test toward inner model was Goodness of Fit (GoF) from the structural model. It was important to be conducted since the objective of this research, besides for hypothesis testing, was to find out the model that was fit to the original data. It was based on the conceptual model. The Goodness of Fit (GoF) test consisted of ten criteria of research. The result of the test can be seen in Table 1 below.

The results show that there is a direct relationship between quality performance of destination $\left(X_{2}\right)$ toward the dependent variable showed the significant and positive impact of destination quality $\left(\mathrm{X}_{2}\right)$ toward relationship marketing $\left(\mathrm{Y}_{1}\right)$ with a coefficient value of 0.27 at a $P$ value of 0.01 ; the significant and positive impact of $X_{2}$ toward visitor satisfaction $\left(Y_{2}\right)$ with a coefficient value of 0.25 at a $P$ value of 0.01 ; and the significant and positive impact of $X_{2}$ toward the visitor behavioral intention $\left(\mathrm{Y}_{3}\right)$ with a coefficient value of 0.12 at a $P$ value of 0.09 .

The Quality of Human Resource Performance $\left(X_{3}\right)$ had a significant and positive impact on relationship marketing $\left(Y_{1}\right)$ with a coefficient value of 0.36 at a $P$ value of 0.01 . It indicates that the high quality of destination performance will give an impact on the increase in relationship marketing of the destination. The $X_{3}$ variable had a significant and positive 
impact on visitor satisfaction $\left(Y_{2}\right)$ with a coefficient value of 0.11 at a $P$ value of 0.1 , indicating that the higher the quality performance of destination is, the higher the visitor satisfaction is. In addition, the $X_{3}$ variable also had a significant and positive impact with a coefficient value of 0.25 at a $P$ value less than 0.01 , indicating that the high quality of destination performance will influence the visitor behavioral intention to make a decision in re-visiting the destination and recommending the destination to other people.

Table 1 - The General Result of SEM Analysis Model Test

\begin{tabular}{|l|c|c|}
\hline \multicolumn{1}{|c|}{ Criteria } & Results & Testing Criteria \\
\hline Average path coefficient (APC) & $\begin{array}{c}\mathrm{APC}=0.184 \\
\mathrm{P}=0.008\end{array}$ & Accepted $(\mathrm{p}<0.05)$ \\
\hline Average R-Squared (ARS) & $\begin{array}{c}\mathrm{ARS}=0.385 \\
\mathrm{P}=0.001\end{array}$ & Accepted $(\mathrm{p}<0.05)$ \\
\hline Average adjusted R-squared (AARS) & $\begin{array}{c}\mathrm{AARS}=0.362 \\
\mathrm{P}=0.001\end{array}$ & Accepted $(\mathrm{p}<0.05)$ \\
\hline Average Block VIF (AVIF) & 1.453 & Accepted (AVIF $\leq 3.3)$ \\
\hline Average Full Collinearity VIF (AFVIF) & 1.628 & Accepted (AFVIF $\leq 3.3)$ \\
\hline Tenenhaus GoF (GoF) & 0.466 & Accepted (GoF $\geq 0.36)$ \\
\hline Sympson's paradox ratio (SPR) & 0.857 & Accepted (SPR $\geq 0.7)$ \\
\hline R-squared contribution ratio (RSCR) & 0.985 & Accepted (RSCR $\geq 0.9)$ \\
\hline Statistical suppression ratio (SSR) & 1.000 & Accepted (SSR $\geq 0.7)$ \\
\hline Non-linear bivariate causality direction ratio (NLBCRD) & 0.929 & Accepted (NLBCRD $\geq 0.7)$ \\
\hline
\end{tabular}

Source: Processed data using WarpPLS analysis, 2018.

The livelihood of the visitor $\left(\mathrm{X}_{4}\right)$ from SEM analysis showed that it had a significant and positive impact with a coefficient as 0.12 at a $P$ value of 0.09 . It means that the high capability owned by the visitor in either humanity, social, capital, physical, or financial will influence the visitor behavioral intention to re-visit and recommend the destination to other people and the willingness to pay more.

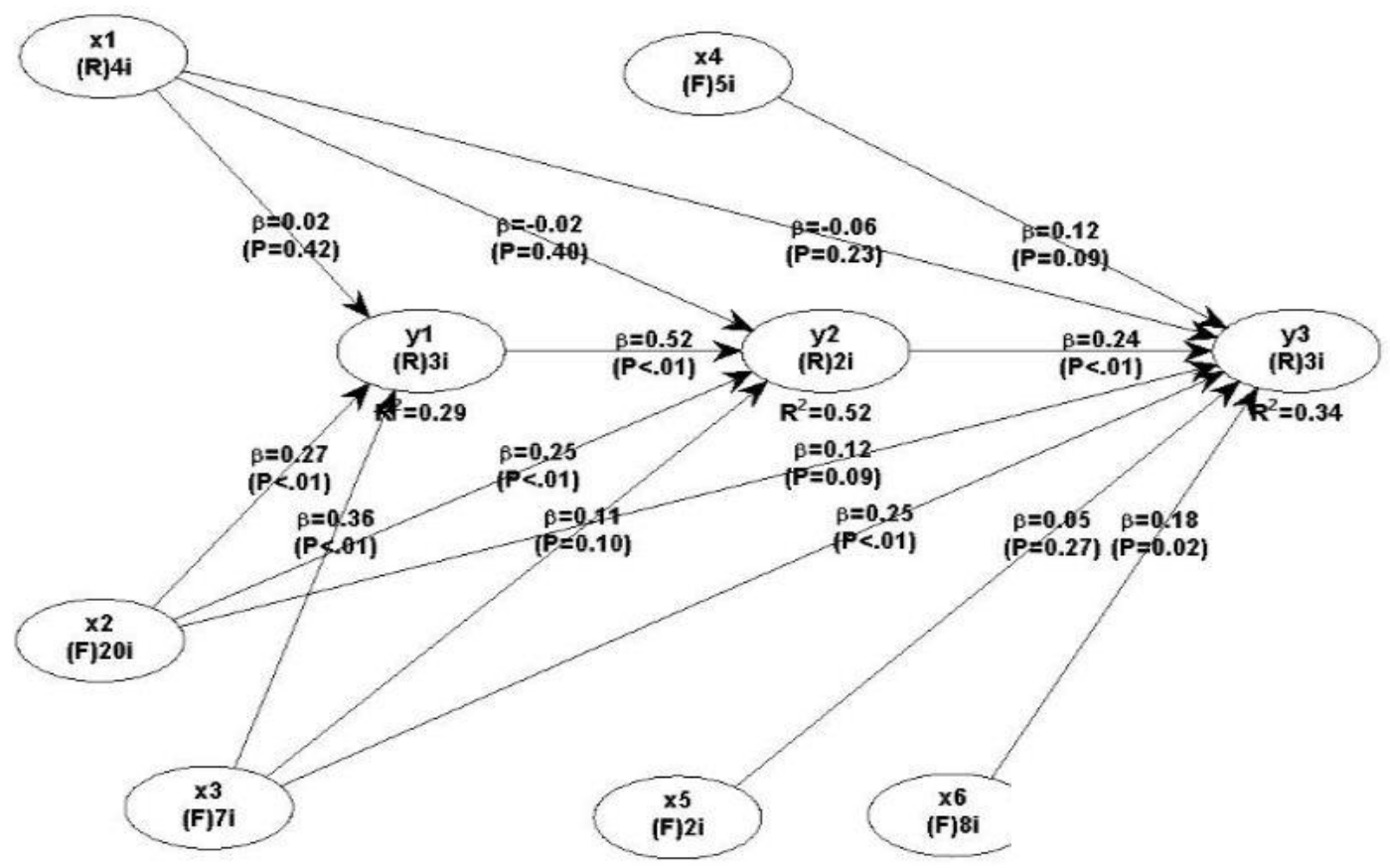

Figure 1 - Structural Model (Source: Primary Data Processed, 2018)

Note: CV $\left(X_{1}\right)=$ Customer Value; $Q D\left(X_{2}\right)=$ the Quality of Destination Performance; $Q H\left(X_{3}\right)=$ the Quality of Human Resource Performance in the Destination; $L V\left(X_{4}\right)=$ the Livelihood of the Visitor; $D I\left(X_{5}\right)=$ Destination Image; RGP $\left(X_{6}\right)=$ Regional Government Performance; $R M\left(Y_{1}\right)=$ Relationship Marketing; VS $\left(Y_{2}\right)=$ Visitor Satisfaction; $B I\left(Y_{3}\right)=$ Behavioral Intention. 
The result of SEM analysis showed that the destination image $\left(X_{5}\right)$ had no significant impact on the visitor behavioral intention toward the destination $\left(Y_{3}\right)$. Meanwhile, the relationship between local government performances $\left(X_{6}\right)$ toward the visitor behavioral intention $\left(Y_{3}\right)$ showed a significant and positive impact at a $P$ value of 0.02 with a coefficient value of 0.18 . It means that good regional government performance will influence the visitor behavioral intention to re-visit and recommend the destination to other people. The regional government performance in this research was the performance in supporting the tourism sector development, especially for agritourism by developing and providing the supported facilities such as road access, information center, promotion activity, transportation facility and infrastructure, and accommodation.

The relationship between relationship marketing $\left(Y_{1}\right)$ toward visitor satisfaction $\left(Y_{2}\right)$ showed a significant and positive impact at a $P$ value less than 0.01 with a coefficient value of 0.52 . It means that good relationship marketing that has been performed will increase visitor satisfaction. The indicators of the relationship in this research are trustworthy, commitment, and communication between the visitor and the manager of the destination place.

The visitor satisfaction $\left(\mathrm{Y}_{2}\right)$ in SEM analysis showed a direct relationship and a significant and positive impact on behavioral intention $\left(Y_{3}\right)$ with a coefficient value of 0.24 at a $P$ value less than 0.01 . This showed that the high visitor satisfaction has significant influence on visitor behavioral intention to re-visit and recommend the destination to other people, and their willingness to pay more.

Additionally, the direct relationship between customers' value $\left(X_{1}\right)$ toward the dependent variables had no significant impact on either relationship marketing $\left(Y_{1}\right)$, visitor satisfaction $\left(Y_{2}\right)$ or Behavioral Intention $\left(Y_{3}\right)$ since it was at a $P$ value of more than 0.1 .

\section{CONCLUSION AND SUGGESTIONS}

The result of SEM analysis shows that the quality performance of destination has a significant impact on relationship marketing, visitor satisfaction, and behavioral intention. Meanwhile, the quality of human resource performance has a significant impact on relationship marketing, visitor satisfaction, and behavioral intention. Additionally, the livelihoods of the visitor, visitor satisfaction, and regional government performance have a significant impact on behavioral intention.

The improvement and the development in all aspects related to agritourism are needed. Based on the data and the result of SEM analysis, it shows that most of the respondents (the visitors) have behavioral intention to recommend the agritourism destination to other people. However, just a few of them who intends to re-visit since the agritourism has a similar concept. Therefore, a creative idea for agritourism concept needs to be developed.

\section{ACKNOWLEDGEMENTS}

We would like to thank to both Indonesian Ministry of Research, Technology, and Higher Education and University of Brawijaya.

\section{REFERENCES}

1. Can, Tu, \& Hoanh. 2013. Application of Livelihood Vulnerability Index to Assess Risk from Flood Vulnerability and Climate Variability- A Case Study in the Mekong Delta of Vietnam. Journal of Environment Science and Engineering. A, Vol 2 No 8.

2. Davidoff, Phillip G, and Davidoff, Doris. 1994. Sales and Marketing for Travel and Tourism. Prentice Hall Career and Technology. New Jersey.

3. Deriawan. 2015. The Influence of Service Quality, Relationship Marketing, and Alternative Attractiveness on Customer Satisfaction and Costumer Commitment and Its Impact. International Journal of Advanced Research. Vol 3 Issue 9. 
4. Gronroos, C. 1988. Service Quality: The Six Criteria of Good Perceived Servive Quality. Review of Business.Winter 1988.

5. Halima Begum, et al. 2014. Tourist's Perceptions towards the Role of Stakeholders in Sustainable Tourism. Procedia- Social and Behavioral Sciences 144 (2014) 313-321.

6. Ivyanno U Canny. 2013. An Empirical Investigation of Service Quality, Tourist Satisfaction, and Future Behavioral Intentions among Domestic Local Tourist at Borobudur Temple. International Journal of Trade, Economics and Finance, Vol 4 No 2.

7. Jankingthong and Gonejanart. 2012. The Relationship of Factors Affecting PostPurchase Behavioral Intention in Tourism Sector. Silapakorn University Journal of Social Sciences, Humanities, and Arts Vol 12(1): 72-90.

8. Kotler, Philip, and G. Amstrong. 2001. Marketing Principles. Prentice Hall International, Inc. Englewood Cliffs. New Jersey. Alih Bahasa: Damous Sihombing. Prinsip-prinsip Pemasaran. Penerbit Erlangga. Jakarta.

9. Parasuraman, A., Valarie A., \& Zeithaml, Berry. 2000. A Conceptual Model of service Quality and Its Implications for Future Research. Journal of Marketing. Vol. 49 pp. 41-50.

10. Sivesan. (2012). Service Quality and Customer Satisfaction: A Case Study - Bangking Sectors In Jaffna District, Sri Lanka. International Journal of Marketing, Financial Services \& Management Research, Vol.1 Issue 10.

11. Solimun. 2016. Pemodelan Persamaan Struktural (SEM) Pendekatan WarpPLS. Universitas Brawijaya. 